\title{
Pembuatan Phantom dari Gips Sebagai Pengganti Tulang Manusia dan Bahan Akrilik Sebagai Pengganti Soft Tissue
}

\author{
Muhammad Sofyan, Alpha Olivia Hidayati, Anita Nur Mayani
}

\begin{abstract}
Background: Phantom is very important in radiodiagnostic teaching method, especially in the laboratory of radiography. Exposing object in making radiograph have to consider the amount of radiation which is received by the object. In addition, phantoms price are relatively expensive. To resolve this issue, researcher made phantom using gypsum as subtitute material for bone and acrylic for soft tissue.
\end{abstract}

Objective: This research is done to know how to make a genu phantom using gypsum as subtitute material for bone and acrylic for soft tissue.

Methods: Research methods are images draft, draft procedures, procedures of use and testing. Phantom testing is done by making radiograph using phantom genu and human genu as object and the the result is compared to know the equation between genu phantom and genu of the human object

Results: The result of testing radiograph showed that phantom structure is almost similar to human bone structure, however there are no bone trabecular. While soft tissue between genu phantom and human genu are almost similar. Based on descriptive analysis of densitometry measurement between genu phantom and human genu evidently there are no differences.

Conclusion: Gypsum can be used as subtitute material for bone and acrylic as subtitute material for soft tissue, however could not show bone trabecular.

Keywords: Phantom, Gypsum, Acrylic

\section{Pendahuluan}

Radiologi adalah ilmu kedokteran untuk
melihat bagian tubuh manusia dengan
menggunakan pancaran atau radiasi gelombang,
baik gelombang elektromagnetik maupun

\footnotetext{
Afiliasi Penulis

Prodi D3 Teknik Radiodiagnostik dan Radioterapi. Stikes Guna Bangsa Yogyakarta

Jl. Ring Road Utara Condongcatur Depok Sleman Yogyakarta telp. 0274-4477701, 4477703, 4477704 fax. 0274-4477702
}

\section{Korespondensi kepada}

M. Sofyan

muhammadsofyan542@gmail.com gelombang mekanik. Hal ini menjadikan tubuh manusia merupakan obyek penting yang harus ada dalam proses pemotretan menggunakan sinar-x, pemindaian dengan CT-Scan, MRI, USG, maupun kedokteran nuklir (Bontrager \& John, 2010).

Dalam proses pempelajaran radiologi, mahasiswa dituntut untuk menguasai teknik pemeriksaan radiologi dengan berbagai posisi pemeriksaan dan kondisi pasien. Sehingga dalam praktikum di laboratorium radiologi mahasiswa akan melakukan eksposi berulang kali menggunakan sinar- $X$ agar trampil dan benar dalam membuat foto radiologi. Dalam kondisi ini, penggunaan obyek manusia dalam praktikum menjadi berbahaya dikarenakan eksposi sinar-X 
kepada obyek secara berulang akan menimbulkan efek somatik dan atau efek genetik (Meredith, 1984)

Berdasarkan kondisi tersebut diperlukan obyek pengganti berupa phantom radiologi agar mahasiswa tidak perlu mendapatkan ekspose sinar-x selama proses pembelajaran. Phantom harus memberikan hasil pencitraan yang sama dengan hasil pencitraan menggunakan obyek manusia. Phantom juga mempunyai struktur tulang yang tertutup dengan gel lunak dalam kulit yang didukung dengan material keras.

Phantom radiologi yang ada di pasaran harganya cukup mahal dan harus impor. Hal ini menjadi kendala bagi institusi pendidikan untuk menyediakan phantom radiologi dalam proses pembelajaran. Untuk itu perlu dilakukan penelitian pembuatan phantom menggunakan bahan lain yang lebih ekonomis namun dapat memberikan hasil pencitraan yang sama setelah diekspose dengan sinar- $\mathrm{X}$.

Gips $\left(\mathrm{CaSO}_{4} \cdot 2 \mathrm{H}_{2} \mathrm{O}\right)$ merupakan mineral evaporit yang mempunyai sifat lunak, pejal, dengan tingkat kekerasan 1,5-2 (skala mohs), berat jenis kelarutan dalam air $1,8 \mathrm{gr} / \mathrm{l}$ pada $0^{\circ} \mathrm{C}$ yang meningkat menjadi $2,1 \mathrm{gr} / \mathrm{l}$ pada suhu $40^{\circ} \mathrm{C}$, akan tetapi menurun lagi pada suhu yang lebih tinggi (Trisna dan Mahyudin, 2009). Resin merupakan polimer, yaitu polimer merupakan makromolekul yang dibangun oleh unit-unit molekul sederhana yang tersusun secara berulang - ulang (Yazici et.,al.2008). Selain resin, pembuatan phantom juga membutuhkan bahan tambahan berupa katalis. Katalis adalah suatu zat yang mempercepat laju reaksi reaksi kimia pada suhu tertentu, tanpa mengalami perubahan atau terpakai oleh reaksi itu sendiri (Farah et.,al.2014). Katalis dalam campuran dengan resin berfungsi untuk mempercepat proses pengerasan (Anand et., al.2014).

\section{Metode}

Langkah-langkah yang dilakukan dalam penelitian ini terdiri atas, pembuatan gambar rancangan, pembuatan cetakan tulang, pembuatan phantom, dan pengujian phantom. Pada pembuatan rancangan diperoleh bentuk seperti gambar 1 . Pada gambar tersebut terlihat phantom tulang yang dibuat adalah Genu (Ballinger \& Philip, 1986).

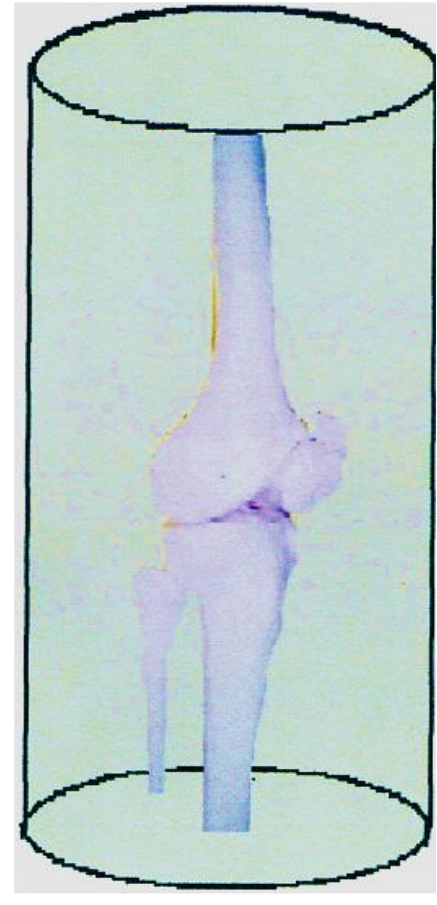

Gambar 1 | Rancangan pembuatan Phantom genu

Kemudian bahan tulang dilapisi oleh silicon cair untuk membentuk cetakan tulang. Langkah selanjutnya setelah bahan silikon tersebut mengeras kemudian dilepas dari bahan tulang untuk dijadikan cetakan pertama. Untuk cetakan kedua cara pencetakannya sama dengan cara pencetakan pertama tetapi pada sisi lain dari tulang tersebut, agar didapatkan dua buah cetakan bagian tulang yaitu cetakan bagian tulang atas dan bagian bawah. Kemudian dilakukan pembuatan cetakan tulang dari bahan gips, dengan cara menuangkan bubuk gips yang sudah dicampur dengan air dan diaduk sampai homogen ke dalam wadah tempat cetakan silikon. Setelah itu ditunggu sampai cetakan tersebut benar-benar mengeras agar siap untuk digunakan. Sehingga diperoleh seperti pada gambar 2 .

Langkah selanjutnya yaitu pembuatan phantom tulang. Bahan gips dicampur dengan air dan diaduk hingga homogen (Gypsum Association, 2007). Kemudian bahan gips yang sudah cair dimasukkan ke dalam masing-masing cetakan tulang dan tunggu hingga mengering. Setelah bahan gips tersebut mengering, langkah selanjutnya adalah mengeluarkan bahan gips tersebut dari cetakan 

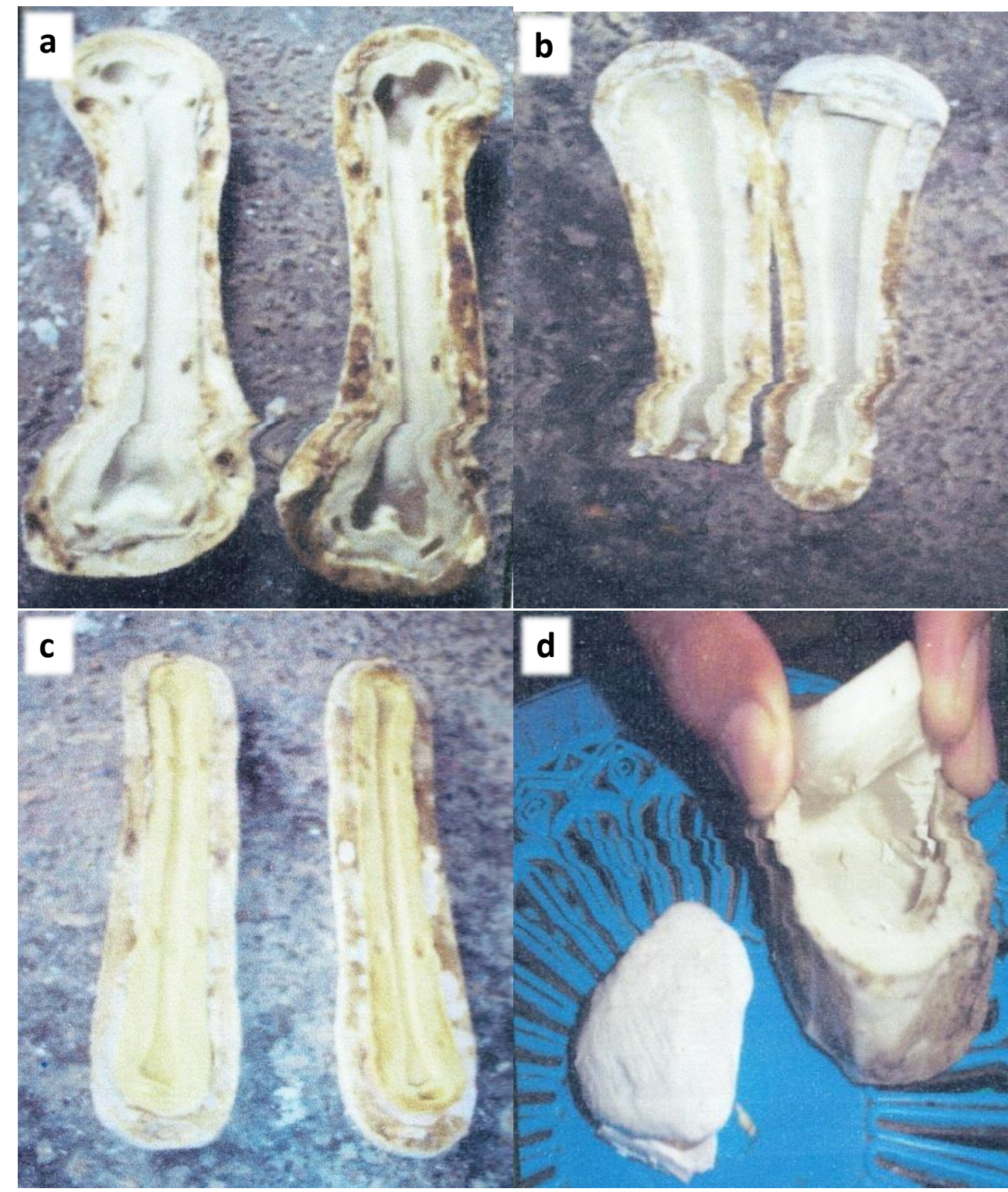

Gambar 2 | Cetakan tulang

a. Cetakan Femur. b. Cetakan Cruris Tibia. c. Cetakan Fibulla. d. Cetakan Patella.

dan dirangkai menjadi sebuah tulang genu dan pengeleman (gambar 3).

Selanjutnya bahan gips yang sudah membentuk sebuah tulang dari proses pencetakan awal, dimasukan ke dalam pipa paralon untuk dilakukan pelapisan bahan yang akan digunakan sebagai bahan soft tissue. Kemudian bahan resin dan katalis dicampur dengan perbandingan 100: 1 (Hewlett, 2003). Setelah kedua bahan tersebut dicampur, kemudian dituangkan ke dalam cetakan pipa paralon yang sebelumnya dilapisi lilin was sebagai lapisan bawah dari pipa paralon. Langkah selanjutnya adalah mengeluarkan bahan akrilik yang sudah mengering dari dalam pipa paralon.

Pada tahap pengujian ini terlebih dahulu dilakukan pembuatan radiograf antara foto genu manusia dengan foto genu phantom. Adapun prosedur pembuatan radiograf yang dilakukan sebagai berikut phantom diletakkan di atas meja pemeriksaan, kaset dengan ukuran $18 \times 24 \mathrm{~cm}$ diletakkan di bawah phantom dengan posisi phantom antero posterior (AP), FFD $100 \mathrm{~cm}$ dan faktor eksposi, dan dilakukan pencucian film yang sudah dieksposi. Kemudian dilihat detail, 


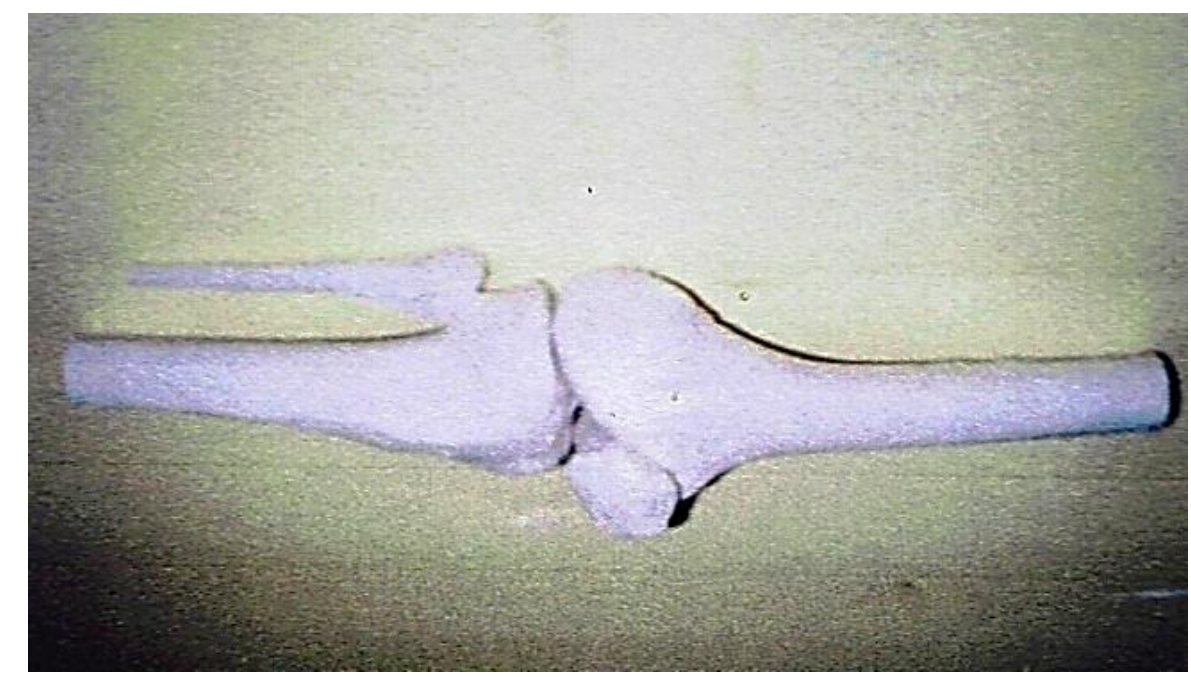

Gambar 3 | Rangkaian tulang Genu dengan pengeleman

ketajaman, kontras, soft tissue dan trabekularnya. Pada radiograf genu manusia ini digunakan faktor eksposi dengan $63 \mathrm{kV}$ dan $8 \mathrm{mAs}$ (Oberholzer, 2005).

\section{Hasil}

Dari hasil pembuatan rancangan pembuatan phantom dihasilkan sebuah phantom dengan spesifikasi tampak $1 / 3$ proximal femur, tampak $1 / 3$ distal cruris, diantaranya tibia dan fibulla, tampak patella, tampak Soft tissue, diameter phantom 8,5 $\mathrm{cm}$, panjang phantom $28 \mathrm{~cm}$, berat total $1,905 \mathrm{~kg}$ (gambar 4). Hasil pengujian perbandingan gambaran radiograf genu manusia dengan genu phantom terlihat pada gambar 5 .

Secara gambaran radiograf antara genu phantom (A) dan genu tulang manusia (B) dapat dibandingkan antara titik 1 dengan $1^{\prime}$ yang menunjukan pada bagian tulang sedangkan titik 2 dengan 2' menunjukkan bagian soft tissue.

Pengukuran dengan menggunakan densitometri digunakan untuk mengukur nilai densitas dari gambaran tulang phantom dan tulang manusia. Pengukuran dilakukan pada tiga titik baik untuk genu phantom maupun genu manusia, yaitu pada bagian tulang patella, pada daerah soft tissue, densitas diluar obyek.

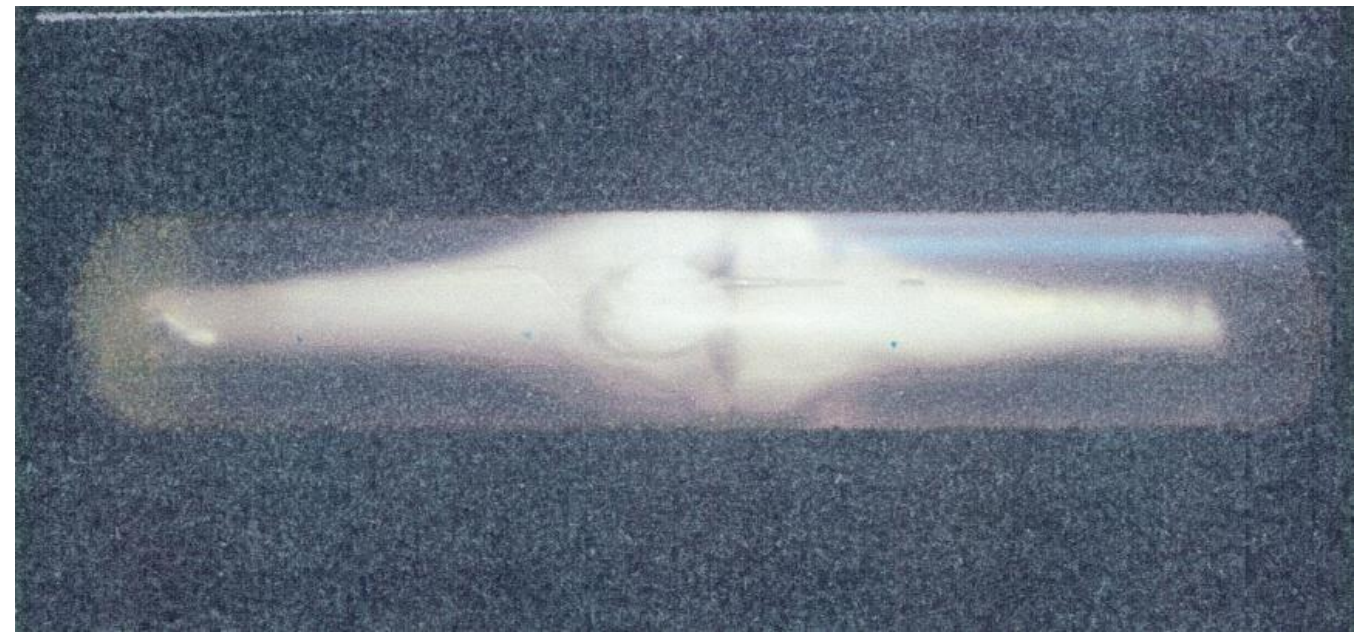

Gambar 4 | Hasil pembuatan phantom 


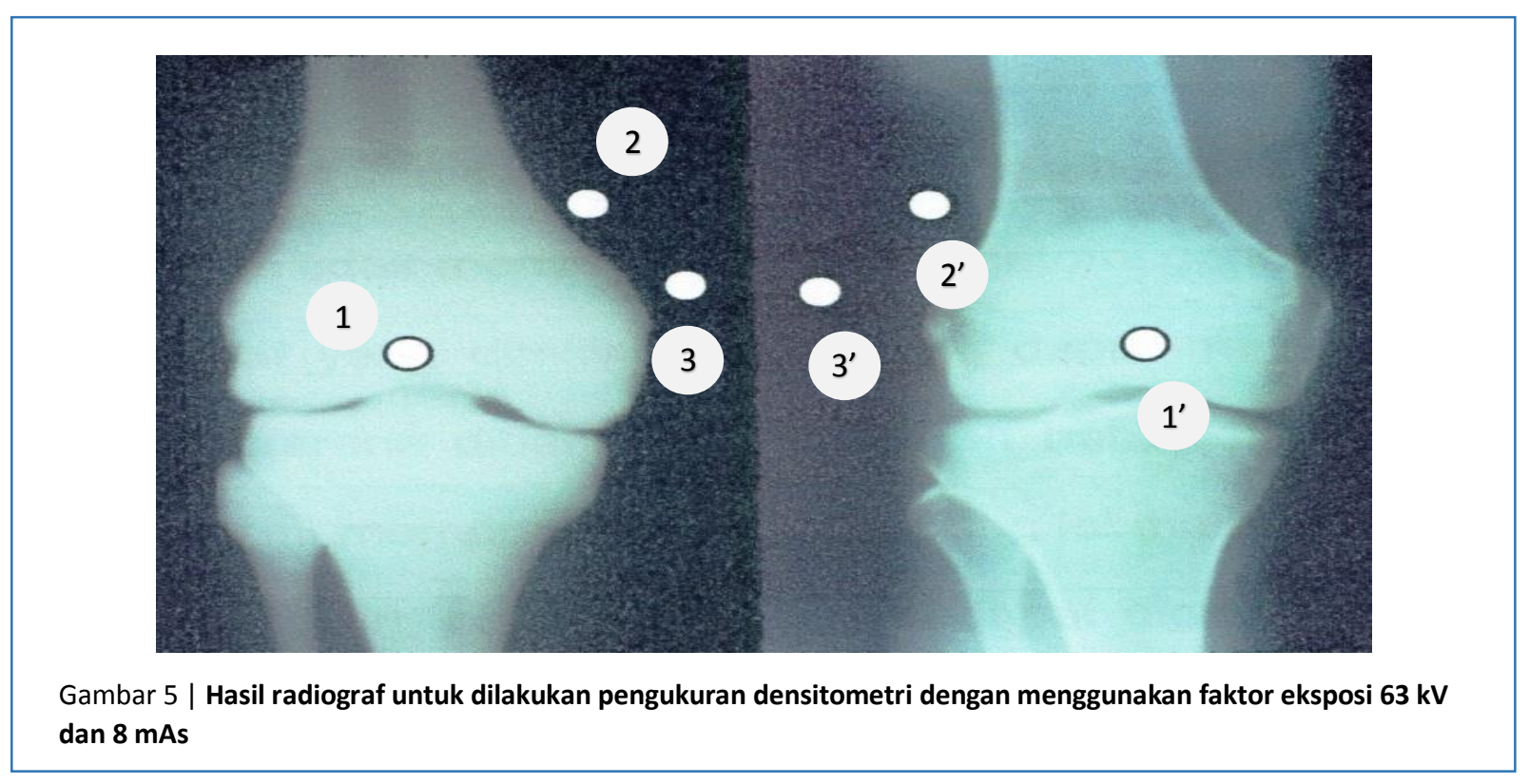

Pengukuran densitometri pada masing-masing tiga titik pengukuran antara genu phantom dengan genu manusia dengan menggunakan faktor ekspose yang sama serta jarak FFD yang sama dan dilakukan pada pencucian automatic yang sama. Hasil pengukuran dengan menggunakan densitometri terlihat pada tabel 1 dan 2 .

Berdasarkan tabel 1 dan 2 terlihat bahwa perbedaan densitas rata - rata tulang phantom dengan tulang manusia sebesar $24 \%$, perbedaan densitas rata - rata soft tissue phantom dengan soft tissue manusia sebesar $45 \%$, perbedaan densitas rata - rata densitas bagian luar obyek phantom dengan densitas bagian luar obyek manusia sebesar $1 \%$.

\section{Pembahasan}

Dari hasil pembuatan phantom ini sangat dipengaruhi oleh tiga bahan utama yaitu gips, resin dan katalis. Dimana gips sebagai pengganti tulang, sedangkan resin dan katalis sebagai pengganti soft tissue. Penggunaan bahan - bahan ini dikarenakan ketersediaan di pasaran relatif mudah diperoleh dan harganya relatif murah. Selain itu gips memiliki kandungan kimia utama yang juga dimiliki oleh tulang, yaitu kalsium (Ca) (Sentano, 1992). Sehingga hasil gambaran radiografnya akan menampakan gambaran yang mirip dengan gambaran tulang manusia, hal ini terlihat pada gambar 5 .

Tabel 1 | Hasil pengujian genu phantom dengan menggunakan densitometri

\begin{tabular}{|rcccc}
\hline Bagian yang diukur & Pengulangan 1 & Pengulangan 2 & Pengulangan 3 & Densitas rata-rata \\
\hline Pengukuran tulang & 1,46 & 1,42 & 1,47 & 1,45 \\
\hline Pengukuran soft tissue & 2,55 & 2,44 & 2,38 & 2,45 \\
\hline Densitas bagian luar obyek & 2,93 & 2,95 & 2,97 & 2,95
\end{tabular}

Tabel 2 | Hasil pengujian genu manusia dengan menggunakan densitometri

\begin{tabular}{rcccc} 
Bagian yang diukur & Pengulangan 1 & Pengulangan 2 & Pengulangan 3 & Densitas rata-rata \\
\hline Pengukuran tulang & 1,23 & 1,27 & 1,15 & 1,21 \\
\hline Pengukuran soft tissue & 1,94 & 2,38 & 1,98 & 2,00 \\
Densitas bagian luar obyek & 2,98 & 2,95 & 2,97 & 2,96
\end{tabular}


Bahan utama dari pembuatan phantom ini adalah resin dan katalis, dengan perbandingan 100 : 1 akan diperoleh campuran yang transparan. Selain itu campuran ini mempunyai kelebihan yaitu tidak mudah pecah dibandingkan dengan menggunakan bahan kaca atau plastik yang samasama memiliki tingkat transparan yang tinggi (Oberholzer, 2008). Tetapi kelemahan utama dalam menggunakan campuran bahan tersebut adalah nilai berat yang dihasilkan cukup tinggi sehingga mempengaruhi kinerja penggunaan.

\section{Pembahasan Hasil Uji Perbandingan Antara Gambaran Radiograf Genu Manusia Dengan Genu Phantom}

Dari pengujian hasil gambaran radiograf antara genu manusia dengan genu phantom didapatkan bahwa struktur phantom (titik 1) mirip dengan tulang manusia (titik $1^{\prime}$ ) tetapi struktur tersebut belum dapat menampakan trabekula. Hal ini dikarenakan belum diperolehnya formula yang pas untuk membentuk trabekula dengan bahan gips. Sedangkan gambaran soft tissue pada radiograf genu phantom (titik 2) tidak terlihat jelas dibandingkan dengan gambaran soft tissue manusia (titik 2').

Selain itu nilai faktor eksposi yang digunakan agar gambaran radiograf pada phantom dapat dinilai secara maksimal, digunakan nilai faktor eksposi $60 \mathrm{kV}$ dan 8 mAs. Hal ini sesuai dengan pesawat $\mathrm{x}$-ray yang digunakan. Pada proses pengujian, hanya dilakukan dengan posisi antero posterior (AP) saja dan belum pada posisi lateral dikarenakan phantom yang dibuat tidak memungkinkan untuk dilakukan foto lateral.

\section{Pembahasan Hasil Pengukuran Densitometri Antara Genu Manusia Dengan Genu Phantom}

Dalam pengukuran densitometri, digunakan faktor eksposi yang sama pada phantom maupun genu manusia agar diperoleh hasil radiograf yang mampu menunjukan kriteria serta memberikan densitas yang benar-benar sama. Untuk melihat densitas radiograf antara genu phantom dan genu manusia maka perlu dilakukan penambahan sedikit mAs apabila digunakan untuk melihat struktur tulang dan dilakukan pengurangan mAs apabila untuk melihat soft tissue atau jaringan lunak (Bontrager, 2010).
Berdasarkan hasil pengukuran densitometri terlihat bahwa terdapat perbedaan rata - rata densitas antara genu phantom dan genu tulang yang relatif kecil dikarenakan kurang dari $50 \%$. Hal ini menunjukan genu phantom dan genu tulang relatif mirip. Sedangkan dilihat dari perbedaan rata - rata densitas antara soft tissue phantom dengan soft tissue manusia terlihat lebih besar daripada nilai perbedaan genu phantom dan tulang (mendekati 50\%). Hal ini menunjukan terdapat kemiripan yang kecil antara soft tissue phantom dan manusia. Sedangkan dilihat dari perbedaan densitas di luar obyek terlihat kemiripan yang paling besar antara phantom dan tulang manusia.

\section{Kesimpulan}

Berdasarkan hasil penelitian di atas dapat disimpulkan bahwa phantom genu dengan menggunakan bahan dasar gips dapat memberikan gambaran radiograf yang mirip dengan tulang genu manusia, namun gambaran radiograf soft tissue dari bahan campuran resin dan katalis belum memberikan gambaran yang mirip dengan gambaran radiograf soft tissue manusia.

\section{Bibliografi}

1. Anand S. Burange, Manoj B. Gawande, Frank L.Y. Lam, Radha V. Jayaram, \& Rafael Luquec. 2014. "Heterogeneously Catalyzed Strategies For The Deconstruction Of High Density Polyethylene:" Journal Plastic Waste Valorisation To Fuels.

2. Ballinger \& Philip, W. 1986. Merril Atlas of Radiographic position and Radiologic Procedure, Sixth Edition, Columbus : CU Mosby Comp.

3. Bontrager L. K, MA, \& John P. Lampignano, Med, RT (R) (RC). 2010. 7th ed. Textbook of Radiographic Positioning and Related Anatomy. Mosby Elsevier, St Louis.

4. Farah Obeid, Joseph Zeaiter, Ala'a H. AlMuhtaseb, \& Kamal Bouhadir. 2014."ThermoCatalytic Pyrolysis of Waste Polyethylene Bottles in A Packed Bed Reactor With Different Bed Materials and Catalysts." Journal Energy Conversion and Management, (85): hal.1 - 6.

5. Gypsum Association. 2007. Application of Gypsum Wallboard on Ceilings toReceive WaterBased Spray Texture Finishes, GA-215-73, Chicago, IL:Gypsum Association.

6. Hewlett, E.R. 2003. Resin adhesion to enamel and 
dentin: A review. J of California Dental Association.

7. Meredith, W.J. 1984. Fundamental Physic of Radiology, Jhon Wright and sons Ltd, Bristol

8. Mochamad Syamsiro, Harwin Saptoadi, Tinton Norsujianto, Putri Noviasri, Shuo Cheng, Zainal Alimuddin \& Kunio Yoshikawa. 2014. "Fuel Oil Production from Municipal Plastic Wastes in Sequential Pyrolysis and Catalytic Reforming Reactors." Journal Energy Procedia, (47): hal. 180 $-188$.

9. Oberholzer, TG, Du Preez IC, \& Kidd M.2005. Effect of LED curing on the microleakage, shear bond strength and surface hardness of a resinbased composite restoration. J Biomater, 26 : 3981-6.

10. Sentano, K.,T. 1992. Diktat Gipsum. Jakarta.

11. Trisna Hilda \& Mahyudin Alimin. 2009. Analisis Sifat Fisis dan Mekanik Papan Komposit Gipsum Serat ljuk dengan Penambahan Boraks (Dinatrium Tetraborat Decahydrate), Jurnal Fisika Unand, 1, (1), 30.

12. Yazici AR, Celik C, Dayangac B, \& Ozgunaltay G. 2008. Effects of different light curing units/modes on the microleakage of flowable composite resins. Eur J Dent ; 2 : 240-4. 